\title{
An unusual cause of cold injury: liquified petroleum gas leakage
}

\section{Nadir bir donma yaralanması nedeni: Sıvılaştırılmıș petrol gazı sızıntısı}

\author{
Nevra SEYHAN, Lorenc JASHARLLARI, Muhammed KAYAPINAR, Nedim SAVACI
}

Liquefied petroleum gas (LPG) is an odorless and colorless gas that is a mixture of hydrocarbons (propane and butane). It is now more commonly preferred among drivers as an autogas throughout the world because it is cheaper than petrol or diesel and produces the same amount of energy. Because of its rapid vaporization and consequent lowering of temperature, it may cause severe cold injuries. A 33-year-old male who suffered from hand burn due to LPG is presented in this article. In LPG-converted cars, if the conversion has not been done properly, LPG may leak. Thus, the public must be informed of this potential danger while undertaking repairs of their vehicles.

Key Words: Autogas; burn; cold injury; LPG.
Sıvılaştırılmış petrol gazı (SPG) renksiz ve kokusuz bir gaz olup propan ve bütan hidrokarbonlarının bir karışımıdır. Petrol ve dizelden daha ucuz olduğu ve aynı enerjiyi sağladığı için tüm dünyada yaygın olarak tercih edilmektedir. Hızlı buharlaşabilme ve buna bağlı 1sıyı düşürebilme özelliğinden dolayı şiddetli donuk yaralanmalarına neden olabilir. Bu yazıda, SPG dönüşümlü arabasını onarmaya çalışırken ellerinde donuk yanığı meydana gelen 33 yaşında erkek hasta sunuldu. SPG'li araçlarda dönüşüm standartlara uygun yapılmadığı takdirde gaz sızıntısı olabilir ve donma yaralanmalarına yol açabilir. Bu potansiyel tehlikeye karşı LPG'li araçların tamiri sırasında oldukça dikkatli olunmalıdır.

Anahtar Sözcükler: Gaz; yanık; donma yaralanması; LPG.
Liquefied petroleum gas (LPG) is the generic name for mixtures of hydrocarbons (mainly $60 \%$ propane and $40 \%$ butane). When these mixtures are lightly compressed, they change from a gaseous state to a liquid. The pressure at which LPG becomes liquid, called its vapor pressure, likewise varies depending on composition and temperature. LPG is colorless, odorless and heavier than air. LPG burns readily in air, and has an energy content similar to petrol and a heat energy twice that of natural gas. This makes it an excellent fuel for heating, cooking and for automotive use.

Liquefied petroleum gas (LPG) comes from two sources. It can be obtained from the refining of crude oil and can also be extracted from natural gas or crude oil streams coming from underground reservoirs. Today, $60 \%$ of LPG in the world is produced from the underground reservoir sources, whereas $40 \%$ is extracted from the refining of crude oil. LPG is much cheaper than petrol or diesel. It burns more cleanly than petrol or diesel and is especially free of the particulates from the latter, thus making it more environmentally friendly.

One of the dangers of LPG is its rapid vaporization and consequent lowering of temperature (the boiling point is between $-42^{\circ}$ and $0^{\circ} \mathrm{C}$, depending on the hydrocarbon mix). LPG can cause severe cold injuries if brought into contact with exposed skin. ${ }^{[1]} \mathrm{A}$ case of cold injury following skin contact with LPG is presented in this article.

\section{CASE REPORT}

A 33-year-old male applied to the emergency department with burn on both his hands. He was consulted to our clinic. He was a teacher and reported that he was trying to repair his LPG-converted car on his own. He checked the solenoid cut-off valve in order to 
understand if there was anything wrong with the system. The engine was running at the time, and there had been a fuel leakage at the point of connection between the pipes and the solenoid valve. He did not realize the gas escape at first. The contact of his exposed hands with the gas lasted only a few seconds. Later, he had the sensations of chill and pain and recognized that his hands had become white. He did not receive any first aid and came directly to the hospital. On his physical examination, he had second-degree superficial burn on the dorsum of both hands with generalized erythema and blisters. His palms were partially involved, not in the usual circumferential pattern that would raise suspicion about a compartment syndrome, and all of his fingers were well perfused. Based on his history, he was diagnosed as frostbite injury with LPG. We applied antibiotic ointment to his hands daily and he was given analgesics for pain relief, and his hands were kept in elevation. The blisters burst spontaneously a few days after his hospitalization. Complete healing was achieved on day 14. Re-epithelization occurred, excluding the need for skin grafting, and he was discharged. On his routine follow-ups, the only abnormality was skin hyperpigmentation of the involved areas. An informed consent was obtained from the patient for the presentation of this case.

\section{DISCUSSION}

The use of LPG as an energy source has increased in many countries. Its cheaper price and its property of being less hazardous to the ozone layer are the main reasons for its increasing popularity as a car fuel. Motor vehicles can now be converted from running on petrol or diesel to LPG. In the United Kingdom, government grants cover up to $40-75 \%$ of the conversion costs. ${ }^{[2]}$

In LPG-converted cars, an isolating valve (solenoid) is positioned between the cylinder and the vaporizer, which automatically closes the gas flow from the tank to the engine compartment. This solenoid valve is closed when the engine is stopped. The tank, which is located at the back of the car, is connected to this valve by copper tubes. The autogas is sent through the copper tubes to the vaporizer, which reduces the pressure of the LPG and thus changes its state from liquid to vapor form. This is then supplied to the engine. ${ }^{[3]}$

Leakage at the connection site of the tubes to the safety shut-off valve is probably due to an improper installation of the LPG kit. Evaporating LPG cools and causes cold burns to the skin. Cold injuries with LPG have been reported previously. ${ }^{[1,2]}$ In these cases, patients were filling their LPG-converted vehicles at the filling station, and the vapor leak was between the gun nozzle and the fuel tank. In our case, the leak was related to the LPG conversion system of the automobile. The vehicle fuel system should be inspected regularly in order to ensure safety, and the installation must be done according to government-approved standards. In Turkey, there are no current laws addressing individuals who perform substandard and illegal conversion.

There are reports about burns caused by explosion of the LPG tanks, ${ }^{[4]}$ but dangers of cold burns from LPG must also be taken into account. ${ }^{[5]}$ Our patient was a teacher and had no knowledge about the cooling effect of the autogas, and thus did not take any preventive measure like wearing gloves while trying to repair the car. In the event of any malfunction, owners should take their vehicle to a LPG-licensed mechanic rather than attempting any repair on their own in an effort to avoid such injuries.

\section{REFERENCES}

1. Wright TC, Kim JB, Currie LJ, Kay AR, Burge TS. Leakage of liquefied petroleum gas during motor vehicle refuelling-a new cause of cold injury. Burns 2006;32:132-3.

2. Murugkar PM, Jones NW, Shokrollahi K, Potokar TS, Drew PJ, Dickson WA. Hand burns sustained whilst refuelling car with LPG (liquefied petroleum gas). Burns 2006;32:515-6.

3. Gümüş M. The effect of LPG using ratio on performance and emission characteristics in a spark ignition engine with dual fuel injection. J Fac Eng Arch Gazi Univ 2009;24:265-73.

4. Bozkurt M, Kulahci Y, Zor F, Kapi E. Burn injuries related to liquefied petroleum gas-powered cars. J Burn Care Res 2008;29:897-901.

5. Bonamonte D, Profeta G, Conserva A, Mazzoccoli S, Foti C, Angelini G. Cold burn from contact with a propane and butane gas blend inside a spray canister used as a hooter. Contact Dermatitis 2008;59:61-2. 